\title{
500 godina protestantizma: baština i otisci u hrvatskom društvu Osvrt na zbornik: Moderna epoha u Hrvatskoj u svjetlu međureligijskih odnosa
}

\section{Centar za demokraciju i pravo Miko Tripalo, Institut za društvena istraživanja u Zagrebu, Visoko evanđeosko teološko učilište u Osijeku, 2019., 401 str.}

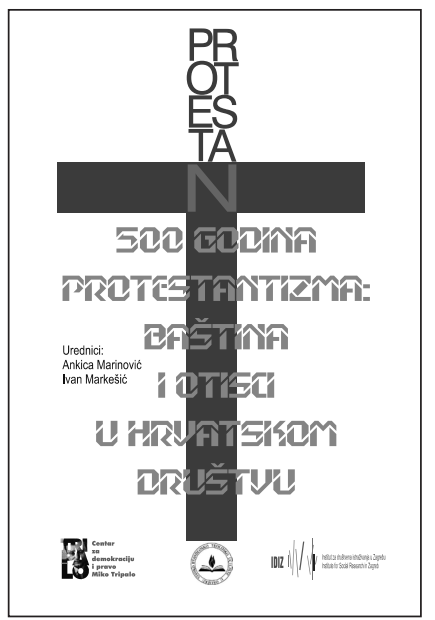

Ova je knjiga neuobičajena i zanimljiva ponajprije zbog jedinstvenog povoda njezinom izdavanju - petstogodišnjica je doista rijedak povijesni jubilej, čija je pojavnost usporediva s velikim kometom. Pored toga, knjiga govori o jednoj vjerskoj tradiciji koja zbog svog začetka u znaku odvažnog suprotstavljanja jednoj (pre)vlasti koja je ipak samo zemaljska, kao i zbog svog dugog trajanja - zacijelo pouzdanog znaka otpornosti vjere - nadmašuje sve pokušaje umanjivanja, pa i negiranja njenog značenja u sklopu izgradnje hrvatskog nacionalnog i kulturnog identiteta. Prije nego što više kažem o sadržaju knjige, iznio bih par uvodnih napomena u cilju osmišljavanja teme o odnosu vjerske većine i manjine, koja čini glavnu okosnicu ovog zbornika.

Prvo, mnogima zvuči neobično, nekima i uvredljivo, kada se konstatira da moderna epoha na Zapadu započinje s nekoliko prvorazrednih zbivanja, među kojima je, možda i na prvom mjestu, protestantska reformacija. Hrvatska nije bila u središtu tog procesa, naravno gledano u parametrima pisanja svjetske povijesti novog vijeka. Ali je, na primjer, prema mišljenju Miroslava Krleže, protestantizam bio epicentar rane modernizacije Hrvatske. Nadalje, zahvaljujući djelima Ernesta Gellnera i Liahe Greenfeld, koja tematiziraju uspon njemačkog protestantizma, kao i engleskog anglikanizma, tog preteče britanskog „trećeg puta“ (sve do Blaira i Brexita), saznajemo više o vjerskim odvajanjima kao osnovama pojave nacionalizma u Europi. Dakako i protureformacijski pokreti, da se ne govori o razdoblju vjerskih ratova, otvorili su više vrata za nacionalizam, koji se i tim putovima - pored napoleonskih ratova, „proljeća naroda“ i raspada austrougarskog i turskog carstva, širio na europsku periferiju, uključujući Hrvatsku. 
Drugo, o učestalim pokušajima spajanja vjerske, teritorijalne i nacionalne pripadnosti govori i umnožavanje granica na kartama Europe u idućih dvjestotinjak godina, opet ponajviše zbog vjerskih ratova. Ono što se iskristaliziralo u dinamici europskog prostora, čije je jedinice zbog čestog mijenjanja oblika jedan povjesničar nazvao „nebuloznim nacijama-državama“, jer je teško razumjeti razloge njihova nastanka možemo nazvati iskustvom bivanja većinom i manjinom.

I treće, kao posljedica prijelaza iz regijsko-religijskog na teritorijalni sustav država popraćenog pomicanjem granica u raznim smjerovima, mnoge su vjerske i nacionalne zajednice postale većinske u jednim, a manjinske u drugim zemljama. Taj „svršeni čin“ ujedno je pragmatički razlog uvođenja načela tolerancije. Etos koji odatle proizlazi može se razumjeti i kantovski i intuitivno: ukoliko želiš dobro pripadnicima svoje zajednice u drugim zemljama, gdje oni čine manjinu, budi obziran kao pripadnik većine prema manjinama u svojoj zemlji. Iako je načelo tolerancije uvedeno još u eri europskih carstava, ono nije dugo funkcioniralo u eri nacija-država. Suvišno je napominjati da u toj eri još uvijek živimo, ali možda nije suvišno dodati da se one nalaze, a da toga često nisu ni svjesne, u ranoj fazi novog svjetskog carstva, tipičnoj po turbulencijama kao i u svakom jurišu na nebo, naime carstvu globalnog kapitalizma.

U nastavku bih predstavio nekoliko naglasaka iz knjige, koji iznose etički nepobitne argumente u prilog međuvjerskoj toleranciji, pri čemu protestantizam ima dvostruko dalekosežno značenje. To je zajednica koja je unijela duh slobodne misli u autoritarno organiziranu crkvu, ali i duh reformacije, koji je dugo tražio prilagodbu u drugim sredinama. Unijela je i dijalog koji, kao što je poznato, traži obostrani pomak od početnih, obično tvrdokornih, pozicija i izvjesnu transformaciju misaonih i praktičnih navika kada je riječ o odnosima prema drugima. To je i dalje ostao najveći izazov ne samo u našoj sredini, pri čemu, valja primijetiti, ekumenski dijalog traje (pre)dugo, kao što i mora biti. Ali često se njegovi ishodi ili ne naziru ili se odvijaju kao po zadanosti reformističkog nauka socijaldemokrata Eduarda Bernsteina, najpoznatijeg političkog Heraklita: kretanje je sve, cilj nije ništa!

U uvodnom poglavlju zbornika urednici i autori Ankica Marinović i Ivan Markešić podsjećaju na široj javnosti manje poznatu činjenicu, a to je da su „hrvatski reformatori činili [...] sve kako bi Bibliju preveli na narodni, hrvatski jezik, pa je tako prvo tiskano izdanje Novoga zavjeta na hrvatskome jeziku iz 1563. godine plod upravo protestantske reformacije“. To je još jedan dokaz da manjina nije uvijek najsretniji termin, budući da se obično povezuje sa sporednim i malobrojnim. Kako pokazuju autori, prema popisu stanovništva 2011. godine katolika je u Hrvatskoj 86,26\%, a protestanata $0,34 \%$. No poput parabole Kahlila Gibrana o kapi vode u kojoj ima svega čega i u oceanu, brojčano mala zajednica sadrži veliku raznolikost: čak su 23 crkve u Hrvatskoj proizišle iz izvorne protestantske tradicije.

Valja istaknuti još jedan paradoks, koji ovaj put spada u „realpolitiku“, koja je često fleksibilnija od doktrinarnih načela. Tako protestantske zajednice, kao i neke druge vjerske zajednice, koriste, kako pišu autori, za neke od njih dobra vremena, koja su nastupila s potpisivanjem ugovora između hrvatske Vlade i Vatikana. Razlozi su opet pragmatički, jer se ista državna obaveza protegnula i na određen broj drugih zajed- 
nica. Jedna misao autorâ zaslužuje posebnu pažnju: „poželjna (ali očito i daleka) budućnost odnosa između katolika i ostalih denominacija u Hrvatskoj bila bi, kako to navodi Enzo Pace, postizanje situacije slične onoj u Njemačkoj između katolika i protestanata: konfesionalne razlike među građanima trebale bi postati tek osnovnim distinktivnim obilježjima u individualnom i kolektivnom ponašanju“ - dakle, nikako politički institucionalizirane u toj mjeri da se u nekim školskim udžbenicima u Hrvatskoj o protestantima piše na način na koji se o njima pisalo u katoličkim krugovima u Europi u 17. stoljeću.

Urednici su ukupno 17 različitih priloga, od empirijskih studija slučajeva do teorijskih eseja o protestantskoj misli, disciplinarno podijelili na povijesne, filozofijske, teologijske i sociologijsko-povijesne (koji su više vezani za današnji trenutak u Hrvatskoj). Prva grupa radova bavi se povijesnim aspektom reformacije u Hrvatskoj. To su radovi Danijela Berkovića Reformacija i protureformacija u brvatskoj povijesnoj recepciji, Zrinke Blažević Historijska istraživanja reformacije u hrvatskom kontekstu: mogućnosti i perspektive, Alojza Jembriha O brvatsko-prevoditeljskom $i$ izdavačkom uraškom pothvatu u doba reformacije te tekst Evangeličke crkve u južnoslavenskim zemljama u 20. stoljeću Anne Marie Gruenfelder. Drugu grupu čine radovi koji razmatraju filozofijske aspekte protestantizma: Sola existentia - Lutherov prinos nastanku suvremene filozofijske hermeneutike Željka Pavića, Martin Luther - filozof savjesti i teolog vjere Gorana Sunajka te Doprinos Matije Vlačića Ilirika protestantskoj bumanističkoj baštini Jure Zovka. U trećoj grupi radova tema su neki teološki aspekti protestantizma. Čine je tri rada: Teološki pluralizam za pluralističko društvo Jadranke Brnčić, Reformacija kao pokret naviještanja „čiste Božje riječi"Stanka Jambreka te Judeo-kršćanska vjerska isključivost izazvana zlouporabom povijesti Dragutina Mataka. Četvrta grupa tekstova bavi se suvremenim aspektima protestantizma iz sociološke, ali i povijesne perspektive: Jasmin Milić napisao je tekst Najstarija hrvatska protestantska župa u Tordincima: prošlost i sadašnjost, Ankica Marinović i Dinka Marinović Jerolimov tekst $A$ što je s našim pravima? Država i manjinske vjerske zajednice: analiza slučaja, Ivan Markešić dva teksta - Doprinos protestantskih vjerskib zajednica obrazovnom sustavu Republike Hrvatske te Krleža o protestantskoj reformaciji i hrvatskim reformatorima, Lidija Matošević, Marina Schumann i Enoh Šeba Od privatnog crkvenog učilišta do Sveučilišnog centra za protestantsku teologiju te Boris Kozjak - Je li kockanje grijeh: o stavovima protestantskih vjerskih zajednica o kockanju.

Izdvojio bih četiri priloga koja se najviše bave već načetom temom odnosa između protestantske manjine i katoličke većine - a nikako zbog veće kvalitete tih priloga u odnosu na druge jer svi su prilozi u knjizi vrlo kvalitetni i u biti nesumjerljivi po svojim specifičnim vrijednostima.

Danijel Berković u tekstu Reformacija i protureformacija u hrvatskoj povijesnoj recepciji bavi se dugotrajnim prijeporima oko etno-religijske osnove hrvatskog (proto) nacionalnog identiteta. Dakako, religioznost je u Hrvatskoj prije Reformacije bila homogena, zapadno kršćanska. Ali je pitanje može li se ta homogenost - ili nacionalna spasenjska drama (u trokutu religija - nacija - domovina) - održati u kasnijim stadijima izgradnje hrvatske nacije. Nakon propitivanja osnovanosti takvog 
shvaćanja hrvatskog identiteta, osobito s obzirom na činjenicu da je recepcija protestantizma u ranijim razdobljima bila pozitivna, a kasnije pretežno negativna, autor zaključuje:

„Unatoč činjenici da je povijesno uvijek, i danas, Hrvatska iznimno većinski katolička zemlja [,] [s]tječe se dojam da je, kao i u neka druga vremena, lakše ukazivati na 'vanjskog' i 'unutarnjeg' neprijatelja. Proporcionalno, protestantska manjina [...] snosi [i] svoj dio odgovornosti."

Može se reći da je takav zaključak proizašao iz dijaloškog sučeljavanja različitih istina ili nazora, i da je to jedini mogući put. Nazovimo ga „asimptotskim“, do nekog diplomatski zaokruženog zajedničkog stajališta o povijesnoj istini, koja je uvijek, htjeli mi to ili ne, pragmatična, suvremenijim historiografskim jezikom rečeno, multiperspektivna. To je ona nepotpuna bliskost različitih nazora, zahvaljujući kojoj možemo razgovarati i - dalje zajedno u miru živjeti.

Prilog Jadranke Brnčić Teološki pluralizam za pluralističko društvo impresionira jednom britkom, ali i u biti točnom konstatacijom:

„Dvije danas dominantne sekularne ideologije - nacionalizam i kapitalizam pogotovo kada se stope u etnoklerokapitalizam, prožele su najvažnije duhovne institucije društva: odgojno-obrazovne, medijske i religijske."

Oslanjajući se na radove Željka Mardešića, inače autora koji je najviše citiran u ovom zborniku, autorica konstatira da je ideologizacija religije u obliku političkog katolicizma, pri čemu „sveto“ postaje identitetska vrijednost, postala prevladavajućom pojavom u društvu. To potkrepljuje zapažanjem spomenutog autora, koje predstavlja i svojevrsno svjedočanstvo vremena u kojem živimo:

„Gotovo je neshvatljivo da smo nekad uspijevali dijalogizirati s nevjernicima, a danas nismo u stanju ni s vjernicima drugačijeg političkog opredjeljenja, što je samo dokaz više da je još uvijek bliža izopačena političnost nego čovjekoljubivo kršćanstvo."

Ipak autorica zaključuje svoj prilog u duhu optimizma koji nije puka fraza, nego obaveza intelektualca da otvori horizont, kao što vozač mora otvoriti svjetlo u tunelu. Brnčić ističe da su vjerski i teološki pluralizmi ne samo mogući nego i nužni, što izvodi iz postulata prema kojem „bez slobodnog čovjeka nema ni slobodnog vjernika niti slobodnog društva“.

Treći prilog predstavlja analitički pomno izrađenu studiju Ankice Marinović i Dinke Marinović Jerolimov pod naslovom A što je s našim pravima? Država i manjinske vjerske zajednice: analiza slučaja. Autorice ukazuju na pojavu institucionalne diskriminacije brojčano malih vjerskih zajednica. Analiziraju slučaj Hrvatske kršćanske koalicije iz 2004. godine u vezi sklapanja ugovora s hrvatskom Vladom koji bi regulirao njihove odnose s državom, kao što je učinjeno u slučaju niza drugih vjerskih zajednica. Vlada je te iste godine donijela nove propise s postroženim uvjetima za 
sklapanje ugovora, a glavni su povijesni i brojčani kriteriji, koje spomenute zajednice ne ispunjavaju. Međutim, nekim drugim vjerskim zajednicama, koje također ne ispunjavaju rečene uvjete, odobreno je sklapanje ugovora. Tako je formalno pravo ustupilo mjesto presedanima. Autorice ističu da je Vlada, koristeći pravo diskrecije, povukla diskriminacijski rez u svojoj politici spram različitih vjerskih zajednica. Međutim, gledajući stvar šire i uspoređujući hrvatsku situaciju sa situacijama u nekim drugim europskim zemljama, autorice ističu da u Hrvatskoj nema „anti-kult“ pokreta ni službenih izvještaja o tzv. „opasnim kultovima i sektama“. Taj zaključak autorica ostaje usporedo s faktičkim stanjem u kojem možemo prepoznati tri „klase“ zajednica: oligopolsku, srednju ili kvazipluralističku i najdonju, koja se sastoji od povijesno novih, „imigrantskih“ zajednica.

Zbornik završava prilogom Ivana Markešića Krleža o protestantskoj reformaciji $i$ brvatskim reformatorima. Autor razmatra Krležine osvrte na protestantizam, osobito njegovu karakterizaciju protestantskog duha kao slobodarskog, smatrajući da je time dao velik doprinos ranoj modernizaciji Hrvatske, kao izraz duhovnog razvoja na osnovi razlikovanja u stavovima, što omogućuje izgrađivanje veze između jednostrukog nacionalnog i višestrukog vjerskog identiteta Hrvatske. Premda Krleža nije bio „muzikalan za religiju“, kako je za sebe govorio Max Weber, sama intelektualna i moralna volja za sintezom daje neusporedivo bolje rezultate od besplodne nacionalističke i u biti sektaške antiteze, tog duha malograđanskog provincijalizma. To je duh koji predugo prevladava u institucijama i mentalitetima našeg podneblja, pa i duboko ispod razine katoličkog aggiornamenta. Markešić nas, nota bene, poziva da ovu knjigu razumijemo kao jedan od mogućih načina ostvarenja Krležine želje:

„Stoga bi zbog povijesne važnosti protestantizam trebao i danas, kao i u Krležino vrijeme, biti 'jedna od onih tema naše kulturne historije koja očekuje svoje pero'."

Na kraju, iznio bih jedno sociološko zapažanje s obzirom na odnos između nacionalnog i religijskog, odnosno većinskog i manjinskog. Naime, socijalna distanca između pripadnika različitih vjerskih skupina, barem u istraživanjima u Hrvatskoj, manja je nego između nacionalnih ili etničkih skupina! Na primjer, katolici su tolerantniji prema pravoslavcima i obrnuto, nego Hrvati prema Srbima i obrnuto. To se, doduše, može objasniti statistički naprosto nepodudarnošću ukupnog broja katolika i ukupnog broja Hrvata. Ali se može razumjeti i kao primjer različitih stereotipova s nejednakim dozama simpatije i antipatije prema drugima. Možda u stavovima prema vjerskim zajednicama dolazi do izražaja veća tolerancija u odnosu na nacionalnu toleranciju. Vjerska se, na primjer, manifestira i u vrijeme vjerskih praznika međusobnim čestitanjima pripadnika različitih vjerskih zajednica. U konačnici, katolici i pravoslavci, kao i protestanti, spadaju u izvorno kršćansku zajednicu i to može biti važan zajednički nazivnik. U slučaju nacionalne prošlosti ti su se zajednički nazivnici nekako pogubili ili utopili u negativne stereotipove. Tako su Hrvati, Srbi i, recimo, (protestantski) Mađari nekada tvorili istu multinacionalnu državu, odnosno carstvo, ali njihove povijesne uspomene nisu privlačne, štoviše, antagonizirajuće su. Isto tako, gotovo je nezamislivo da Hrvati ili Srbi čestitaju jedni drugima državne praznike. 
Kako bilo, vodstva vjerskih zajednica, u usporedbi s onima nacionalnih, imaju veći autoritet u oblikovanju suvremene društvene pa i političke svijesti, prije svega u politici emocija, koja je sastavni dio politike identiteta, često i najvažniji. Stoga snose i veću odgovornost pred domaćom i međunarodnom javnošću, makar to podrazumijevalo suprotstavljanje svakoj politici koja radije dijeli nego spaja narode po vjeri ili naciji. Bila bi to ponovno velika povijesna tragedija da vodstva vjerskih zajednica dočekaju nespremna novu veliku krizu sekularne ideologije broj jedan, jer je globalna, naime krizu globalnog kapitalizma. Njegovi sadašnji trgovinski ratovi i njegovo kruppovsko zatvaranje u nacionalne granice spremno dočekuju, kao i 1930-ih, fašistoidni demagozi. Od vjerskih vođa u takvoj krizi valja očekivati nešto drugo, kako bi rekao Max Weber, vjersku i etičku, egzemplarnu virtuoznost. To je obraćanje javnosti koje prvo ima na umu kako ljude naučiti da žive kao međusobno bliska bića, nikako kao krvni neprijatelji, kao utjelovljenja nekih naopakih imaginarija i lažnih povijesnih „istina“, koja istom inercijom loših navika zamjenjuju opće partikularnim interesima i pojedinačne kolektivnim zločinima. U takvim se falsifikatima čovjekova lika poništavaju sve vrijednosti, uključujući i religijska uvjerenja. To su vrijednosti koje čovjeka - kako bi rekla Simone Weil - uzdižu na jednu višu razinu, koju naziva milošću, a bivaju razvikani zazorni, odbijajući i poništavajući stavovi koji ljude gravitacijskom silom potpomognutom pucnjevima vraćaju u anorganski svijet.

Vjeran Katunarić

Sveučilište u Zadru, Odjel za sociologiju 